Creative Commons User License: CC BY-NC-ND

Abstracted by: EBSCOhost, Electronic Journals Service (EJS),

Google Scholar, Journal Seek, Scientific Commons,

Food and Agricultural Organization (FAO), CABI and Scopus

http://eoi.citefactor.org/10.11226/v25i4
Journal of Agricultural Extension

Vol. 25 (4) October, 2021

ISSN(e): 24086851; ISSN(Print); 1119944X

http://journal.aesonnigeria.org

http://www.ajol.info/index.php/jae

Email: editorinchief@aesonnigeria.org

\title{
Training Needs of N-Power Agro-Beneficiaries in Kwara State, Nigeria
}

https://dx.doi.org/10.4314/jae.v25i4.4

\author{
Aderinoye-Abdulwahab, Sidiqat, Adeyemi \\ Department of Agricultural Extension and Rural Development, \\ University of Ilorin, Ilorin, Nigeria \\ Corresponding Author: sidiay@yahoo.com +2348033594496
}

Mohammed, Jamiu MohammedDepartment of Agricultural Extension and Rural

Development,

University of Ilorin, Ilorin, Nigeria

mohammedmohammedjamiu@gmail.com; +2347031095959

\section{Issa, Fadlullah Olayiwola}

National Agricultural Extension and Research Liaison Services,

Ahmadu Bello University, Zaria, Nigeria

issafola@gmail.com +2348033339312

\begin{abstract}
This study assessed the training needs of N-Power Agro beneficiaries in Kwara State. Simple random sampling was used to select 216 respondents using a questionnaire to collect data while percentages, mean, standard deviation and Pearson Product Moment Correlation (PPMC) were used to analyze the data. Training of respondents was assessed using job/task and skill gap analysis. Results showed that rules and regulation governing the job ( $\bar{x}=5.69)$, knowledge acquisition $(\bar{x}=1.99)$, field practices $(\bar{x}=1.70)$, record keeping $(\bar{x}=1.69)$, and extension service delivery methods $(\bar{x}=1.59)$ were the areas where training were needed. Extension service delivery methods $(\bar{x}=3.17)$ was identified as the only gap which training could address. It was found that age $(r=0.341)$, sex $(r=0.095)$ and educational status $(r=0.180)$ were favorable socioeconomic factors determining training needs of respondents at $p \leq 0.05$ level of significance. A significant gap exists in what the beneficiaries already know and what they now need to know as they have not been undergoing adequate capacity building training; hence there is a dire need for intensive training to cover the existing gaps for effective productivity of the $\mathrm{N}$-agro beneficiaries in Kwara State.
\end{abstract}

Keywords: Empowerment, training, capacity development, human resources, productivity.

\section{Introduction}

Successive governments in Nigeria had embarked on different youth empowerment development policies, projects and programmes aimed at empowering the youths in the country so as to make them contribute meaningfully to the development of the nation. Such youth empowerment programmes include Graduate Internship Scheme (GIS), Youth Initiative for Sustainable Agriculture in Nigeria (YISA), Subsidy Reinvestment and Empowerment programme (SURE-P), Youth Enterprise with 
Creative Commons User License: CC BY-NC-ND

Abstracted by: EBSCOhost, Electronic Journals Service (EJS), Google Scholar, Journal Seek, Scientific Commons,

Food and Agricultural Organization (FAO), CABI and Scopus
Journal of Agricultural Extension

Vol. 25 (4) October, 2021

ISSN(e): 24086851; ISSN(Print); 1119944X

http://journal.aesonnigeria.org

http://www.ajol.info/index.php/jae

Email: editorinchief@aesonnigeria.org

Innovation in Nigeria (YouWIN), National Directorate of Employment (NDE) scheme and N-power (Ogunmodede, Ogunsanwo and Manyong, 2020; Yami et al., 2019).

The N-Power scheme is the employability and enhancement programme of the Federal Government of Nigeria, aimed at imbibing the learn-work enterprise culture in youth between the ages 18-34 (N-Power-N-SIP, 2019). Specifically, the programme, which took off in December, 2016 was designed to provide a stop-gap for 500,000 unemployed graduates of tertiary institutions over the following two years (Bennel, 2017). According to Ogbette, Bernard-Oyoyo and Okoh (2019), the aims of the N-power programme included; reducing the rate of unemployment in the country, technical skills and employability ability, facilitate the transfer of entrepreneurial, government diversification policy and to bring active solution to public service. Studies have shown that the programme have benefited the beneficiaries in various ways. Bisong (2019) reported positive contribution of the programme to socioeconomic wellbeing of beneficiaries and Odey and Sambe (2019) found that the programme contributed to empowerment of youth through poverty reduction and financial empowerment of beneficiaries. The programme is available for graduate and non-graduates. The graduate's category is further divided into three areas namely, the $\mathrm{N}-$ Teach, $\mathrm{N}$-Health and $\mathrm{N}$-Agro.

$\mathrm{N}$-Power Agro beneficiaries are intended to provide advisory services to farmers across the country (Odey and Sambe, 2019). They are expected to disseminate the knowledge that has been amassed by the Federal Ministry of Agriculture and Rural Development in the area of extension services, helping farmers in their decisionmaking and ensuring that appropriate knowledge is implemented to obtain the best results on farms (Akujuru and Enyioko, 2019). The programme is geared towards equipping its beneficiaries with necessary and meaningful skills through training to be self-employed (N-Power Information Guide, 2017).

Training is essential for $\mathrm{N}$-agro beneficiaries to improve their knowledge and service delivery. The importance of training cannot be overemphasized due to its effect on message dissemination, bridging the gap between farmers and various researchers thereby improving productivity and yield, training would also help in improving the relationship between farmers and extension service. The training given to employee has a lot of advantages on the service to be delivered by the beneficiaries (Abera, 2021; Latopa and AbdRashid, 2015). Many of the beneficiaries do not have much practical knowledge during their course of study and as beneficiaries of the N-power programme, they will do a lot of field work.

It is worthwhile to note that most of the beneficiaries are unemployed fresh graduates of agriculture with little or no practical experience (Adeyanju, Mburu and Mignouna, 2021). Personal interaction by authors of this study with few beneficiaries has shown that many of the $\mathrm{N}$-agro beneficiaries have received little or no training that can equip them to be self-employed after the programme. In the same vein, Bisong (2019) had suggested that government should introduce mandatory training and workshops in area of agriculture for N-power volunteers to increase their employability after the expiration of the scheme. Conducting such training requires 
Creative Commons User License: CC BY-NC-ND

Abstracted by: EBSCOhost, Electronic Journals Service (EJS), Google Scholar, Journal Seek, Scientific Commons,

Food and Agricultural Organization (FAO), CABI and Scopus
Journal of Agricultural Extension

Vol. 25 (4) October, 2021

ISSN(e): 24086851; ISSN(Print); 1119944X

http://journal.aesonnigeria.org

http://www.ajol.info/index.php/jae

Email: editorinchief@aesonnigeria.org

huge resources and to avoid wastage, there is need to identify the gap between what is known and unknown where such will focus. In response to this problem in the Nagro category, no study has been conducted to identify the information gap of the beneficiaries in $\mathrm{N}$-agro category. This empirical data is needed to influence the $\mathrm{N}$ power programme training policy to better equip the existing and prospective beneficiaries. It is against this background that this study seeks to assess the training needs of $\mathrm{N}$-agro beneficiaries in Kwara State. Specifically, the study sought to: (i) identify areas where training is needed by the respondents; (iv) identify the sources of information used by the respondents; and (v) determine the constraints to training activities of respondents in the study area.

\section{Hypothesis}

$\mathrm{Ho}_{1}$ : There is no significant relationship between the socio-economic characteristics of $\mathrm{N}$-power agro beneficiaries and their training needs.

\section{Methodology}

This study was conducted in Kwara State of Nigeria. The State has an area of land totaling $32,500 \mathrm{Km}^{2}$ with Guinea Savannah Vegetation. Geographically, the State is situated between latitude $7^{0} 201$ and $11^{\circ} 051$ North of the equator; longitude $2^{0} 51$ and $6^{0} 451$ East of the prime meridian. Kwara State consists of sixteen local government areas. The State population is 2.37 million based on the 2006 Census, with $2.6 \%$ annual growth rate in Nigeria. Kwara State population should be 4.10 million people in 2019 (NBS, 2017).

The population of the study consists of all N-power Agro beneficiaries in Kwara State. A three-stage sampling procedure was employed for the study. Stage one: involved random selection of fifty percent $(50 \%)$ of the Agricultural Development Programme (ADP) zones in the state, and the selected zones are Zone C \& D. At stage two: eighty percent (80\%) of the local government areas (LGAs) were randomly selected i.e. four (4) of five (5) LGAs were selected from Zone C and six (6) of seven (7) LGAs were selected from Zone D, making a total of ten (10) LGAs. The third stage was also a random selection of ten percent $(10 \%)$ of $\mathrm{N}$-power agro beneficiaries from each of the selected LGAs to make a total sample size of two hundred and sixteen (216) respondents. The data were collected with the aid of a questionnaire and analyzed using percentages, means, standard deviation and ranks.

The independent variable comprised respondents' sources of information and constraints hindering their training. Scale used to assess sources of information were measured as: often $=3$, sometimes $=2$ and never $=1$ while scale used to assess constraints to training activities were measured as: very severe $=4$, severe $=3$, less severe $=2$ and not severe $=1$. This study adopted the Food and Agricultural Organization model to measure the dependent variable which is the training needs of $\mathrm{N}$-power agro beneficiaries in Kwara State. The model consists of two types of analyses namely: Task analysis and skill-gap analysis. 
Creative Commons User License: CC BY-NC-ND

Abstracted by: EBSCOhost, Electronic Journals Service (EJS), Google Scholar, Journal Seek, Scientific Commons,

Food and Agricultural Organization (FAO), CABI and Scopus
Journal of Agricultural Extension

Vol. 25 (4) October, 2021

ISSN(e): 24086851; ISSN(Print); 1119944X

http://journal.aesonnigeria.org

http://www.ajol.info/index.php/jae

Email: editorinchief@aesonnigeria.org

Task analysis involved assessing frequency, importance and difficulty in learning. Scale used to assess these components were assigned numerals as follows: frequency of performance (seldom $=1$, occasionally $=2$, monthly $=3$, weekly $=4$, daily=5), importance of training (marginally important=1, moderately important $=2$, and extremely important $=3$ ), difficulty in learning (easy $=1$, moderate difficulty $=2$, very difficult $=3$, extremely difficult $=4$ ).

Skill-gap analysis was assessed with current proficiency. Current proficiency was measured as: $1=$ cannot complete any part, $2=$ can complete less than half the task; $3=$ can complete more than half but less than the total; $4=$ can complete the entire task but takes too long; $5=$ complete the task within standard time. The proficiency rating was done and those tasks that appear to have low proficiency were thereby reviewed. Low proficiency means that there is a gap between what is desired and what the situation is currently.

Decision rule: to know if proficiency is the problem. Total number of numerals assigned to scales/number of scale (i.e $1+2+3+4+5=15 / 5=3$ ) Therefore, the mean score of 3 is the benchmark. Any mean score below 3 were considered "yes" as area where proficiency is a problem. Any mean score of 3 and above were considered "no" as area where proficiency is not a problem. Can it be solved by training? Average of the number of scale (i.e $5 / 2)=2.5$ were used to decide if skill gap can be solved through training. A scale of 2.5 was therefore considered as threshold. Scale below 2.5 was regarded as "yes" for skill gaps that can be solved by capacity building.

The Pearson Product Moment Correlation (PPMC) was used to test the relationship between selected socio-economic characteristics and the training needs of beneficiaries.

\section{Results and Discussion}

\section{Training Needs of $\mathrm{N}$-power Agro beneficiaries}

Table 1 shows that rules and regulation governing the job $(\bar{x}=5.69)$, knowledge acquisition $(\bar{x}=1.99)$, field practices $(\bar{x}=1.70)$, record keeping $(\bar{x}=1.69)$, extension service delivery methods $(\bar{x}=1.59)$, and project evaluation $(\bar{x}=1.53)$ were the on-thejob skills that were lacking and would be highly beneficial if acquired. In addition, it was found through observation and personal discussion with the beneficiaries that there was no document detailing the job description for beneficiaries. This implies that significant gap exists in what the respondents already know and what they now need to know; hence there is a dire need to cover the existing gaps for effective productivity of the beneficiaries. The current study suggests that the $\mathrm{N}$-agro beneficiaries in Kwara State would need to be equipped with basic orientation and continuous on the job training; before and during the programme so that they can effectively carry-out their duties. This assertion is in order with that of Abera (2021) that training of personnel must be in place with relevant facilities in order to accomplish successful programmes. 
Creative Commons User License: CC BY-NC-ND

Abstracted by: EBSCOhost, Electronic Journals Service (EJS), Google Scholar, Journal Seek, Scientific Commons,

Food and Agricultural Organization (FAO), CABI and Scopus

http://eoi.citefactor.org/10.11226/v25i4
Journal of Agricultural Extension

Vol. 25 (4) October, 2021

ISSN(e): 24086851; ISSN(Print); 1119944X

http://journal.aesonnigeria.org

http://www.ajol.info/index.php/jae

Email: editorinchief@aesonnigeria.org

Table 1: Task analysis of $\mathrm{N}$-Power agro beneficiaries

\begin{tabular}{lll}
\hline Job activities & Mean & $\begin{array}{l}\text { Standard } \\
\text { Deviation }\end{array}$ \\
\hline Rules and regulation governing job & $5.69^{*}$ & 0.24 \\
Knowledge acquisition & $1.99^{*}$ & 0.22 \\
Field practices & $1.70^{*}$ & 0.01 \\
Record keeping & $1.69^{*}$ & 0.76 \\
Extension service delivery methods & $1.59^{*}$ & 0.13 \\
Project evaluation & $1.53^{*}$ & 0.11 \\
Report writing & 0.84 & 0.22 \\
Writing new policies & 0.84 & 0.28 \\
Budget and financial statement & 0.22 & 0.98 \\
Training on use of ICT & 0.36 & 0.24 \\
\hline
\end{tabular}

Decision: *Training is needed.

Furthermore, the proficiency analysis in Table 2 presents the specific gap areas that can be addressed by training. The table shows that skill for extension service delivery methods was the only skill that can be addressed by training. Proficiency in extension service delivery methods is key; to performing the advisory service role which is the main goal of establishing the N-power Agro programme. According to Odey and Sambe (2019), the primary role of N-Power Agro beneficiaries is to provide advisory services to farmers across the country. Akujuru and Enyioko (2019) added that the N-Power Agro beneficiaries are expected to disseminate the knowledge that has been amassed in the area of extension services by helping farmers in their decision-making and ensuring that appropriate knowledge is implemented to obtain the best results on farms in order to increase productivity. 
Creative Commons User License: CC BY-NC-ND

Abstracted by: EBSCOhost, Electronic Journals Service (EJS), Google Scholar, Journal Seek, Scientific Commons,

Food and Agricultural Organization (FAO), CABI and Scopus

http://eoi.citefactor.org/10.11226/v25i4
Journal of Agricultural Extension

Vol. 25 (4) October, 2021

ISSN(e): 24086851; ISSN(Print); 1119944X

http://journal.aesonnigeria.org

http://www.ajol.info/index.php/jae

Email: editorinchief@aesonnigeria.org

Table 2: Skill gap analysis of $\mathbf{N}$-power agro beneficiaries

\begin{tabular}{lll}
\hline Job activities & Mean & $\begin{array}{l}\text { Standard } \\
\text { deviation }\end{array}$ \\
\hline Extension service delivery methods & $3.17^{*}$ & 0.22 \\
Field practices & 1.25 & 0.34 \\
Knowledge acquisition & 1.21 & 0.12 \\
Rules and regulation governing job & 0.80 & 0.11 \\
Record keeping & 0.77 & 0.27 \\
Project evaluation & 0.64 & 0.11 \\
Report writing & 0.58 & 0.07 \\
Office practices & 0.54 & 0.18 \\
Use of ICT & 0.29 & 0.23 \\
Delegation of work & 0.23 & 0.45 \\
Budget and financial statement & 0.18 & 1.01 \\
Writing of new policies & 0.07 & 1.22 \\
\hline
\end{tabular}

Source: Field survey (2020). *Can be addressed by training.

\section{Sources of Information of Beneficiaries}

Table 3 shows that social media $(\bar{X}=1.20)$, N-power group/place of assignment $(\bar{X}=0.65)$ and radio $(\bar{X}=0.21)$ were the foremost sources of information among respondents. It was observed that a significant amount of the $\mathrm{N}$-agro beneficiaries $(72 \%)$ are ICT compliant as they reported that they do get information through the social media. It can be inferred that the internet is a global village, these findings can be supported with the report of USAID (2017) where it was stated that the internet is already anecdotal evidence of youth integrating technology systems in their activities.

Table 3: Sources of information

\begin{tabular}{lll}
\hline Sources of information & Mean score & Standard deviation \\
\hline Social media & 1.20 & 0.24 \\
N-power group/ place of assignment & 0.65 & 0.11 \\
Radio & 0.21 & 0.06 \\
Family/friend & 0.19 & 1.07 \\
Print/media & 0.10 & 0.98 \\
Television & 0.09 & 0.67 \\
\hline
\end{tabular}

Source: Field survey (2020)

\section{Constraints to Training Activities}

Table 4 shows that lack of funds $(\bar{x}=1.75)$, unmotivated staff $(\bar{x}=1.73)$, and inadequate training equipment/facilities $(\bar{x}=1.69)$ were the leading constraints inhibiting the beneficiaries from adequate capacity building training. In a related study, Adesina and Efuruoku (2020) similarly found inadequate training facilities as constraints to participation in Youth-in-Agriculture programme. According to Abera, (2021), proper funding is essential to facilitate the implementation of extension 
Creative Commons User License: CC BY-NC-ND

Abstracted by: EBSCOhost, Electronic Journals Service (EJS),

Google Scholar, Journal Seek, Scientific Commons,

Food and Agricultural Organization (FAO), CABI and Scopus

http://eoi.citefactor.org/10.11226/v25i4
Journal of Agricultural Extension

Vol. 25 (4) October, 2021

ISSN(e): 24086851; ISSN(Print); 1119944X

http://journal.aesonnigeria.org

http://www.ajol.info/index.php/jae

Email: editorinchief@aesonnigeria.org

programmes. Regasa, Ulimwengu and Josee (2016) also speculated that the effectiveness of training activities depends on the regular and timely release of training funds and provision of mobility.

Other notable constraints to training were administrative bottleneck ( $\bar{x}=1.52)$, lack of proper organization $(\bar{x}=1.13)$, training programme not motivating $(\bar{x}=0.79)$, unconducive training environment $(\bar{x}=0.78)$ long distance of the training institute $(\bar{x}=0.33)$, dearth of subject matter specialists $(\bar{x}=0.17)$, family problem/pressure $(\bar{x}=0.15)$, lack of time $(\bar{x}=0.05)$, and poor attitude of trainers $(\bar{x}=0.03)$. 
Creative Commons User License: CC BY-NC-ND

Abstracted by: EBSCOhost, Electronic Journals Service (EJS), Google Scholar, Journal Seek, Scientific Commons,

Food and Agricultural Organization (FAO), CABI and Scopus

http://eoi.citefactor.org/10.11226/v25i4
Journal of Agricultural Extension

Vol. 25 (4) October, 2021

ISSN(e): 24086851; ISSN(Print); 1119944X

http://journal.aesonnigeria.org

http://www.ajol.info/index.php/jae

Email: editorinchief@aesonnigeria.org

Table 4: Constraints to training activities in the study area

\begin{tabular}{lll}
\hline Constraints & $\begin{array}{l}\text { Mean } \\
\text { score }\end{array}$ & Standard deviation \\
\hline Lack of fund/inadequate fund & 1.75 & 0.35 \\
Unmotivated staff & 1.73 & 0.29 \\
Inadequate training & 1.69 & 0.26 \\
equipment/facilities & & \\
Administrative bottleneck & 1.52 & 0.19 \\
Lack of proper organization & 1.13 & 0.19 \\
Training programme not motivating & 0.79 & 0.35 \\
Un-conducive training environment & 0.78 & 0.23 \\
Long distance of the training & 0.33 & 0.27 \\
Institute & & \\
Dearth of subject matter specialists & 0.17 & 0.31 \\
Family problem/pressure & 0.15 & 0.69 \\
Lack of time & 0.05 & 0.73 \\
Poor attitude of trainers & 0.03 & 0.45 \\
\hline Sourc Field survey, 2020
\end{tabular}

Source: Field survey, 2020. * Multiple responses. 
Creative Commons User License: CC BY-NC-ND

Abstracted by: EBSCOhost, Electronic Journals Service (EJS),

Google Scholar, Journal Seek, Scientific Commons,

Food and Agricultural Organization (FAO), CABI and Scopus

http://eoi.citefactor.org/10.11226/v25i4
Journal of Agricultural Extension

Vol. 25 (4) October, 2021

ISSN(e): 24086851; ISSN(Print); 1119944X

http://journal.aesonnigeria.org

http://www.ajol.info/index.php/jae

Email: editorinchief@aesonnigeria.org

\section{Relationship between socio-economic characteristics of N-power Agro beneficiaries and training needs}

Result, as shown on Table 5, highlights the relationship between the socio-economic characteristics and training needs of beneficiaries. Findings show that there was positive significance between the socio-economic characteristics age $(r=0.341)$, sex $(r=0.095)$ and educational status $(r=0.180)$ and the training needs of $\mathrm{N}$-power agro beneficiaries. These findings imply that age, sex and educational status are favorable factors determining training needs among respondents. Higher levels of education determine the quality of skills of any individual, their allocated abilities, efficiency, and how well they are informed of the innovations and technologies around them. Additionally, Adeyanju, Mburu \& Mignouna (2020) also reported that educational level positively influences the beneficiaries' participation in training; therefore, it is not surprising that this study found that educational status of N-power agro beneficiaries will play a significant role in building their capacity.

Table 5: Relationship between socio-economic characteristics and training needs

\begin{tabular}{ll}
\hline Variables & $\boldsymbol{r}$-value \\
\hline Age & $0.341^{*}$ \\
Sex & $0.095^{\star}$ \\
Marital status & 0.037 \\
Household size & 0.156 \\
Educational status & $0.180^{\star}$ \\
Years spent & 0.778 \\
\hline
\end{tabular}

${ }^{*} \mathrm{P} \leq 0.05$

\section{Conclusion and Recommendation}

$\mathrm{N}$-power agro beneficiaries lack adequate proficiency in certain areas of capacity building and this is essential for efficient productivity to be achieved. Specifically, the beneficiaries require capacity building training in the areas of rules and regulation governing the job, knowledge acquisition, field practices, record keeping, extension service delivery methods and project evaluation. It is pertinent to state that even though the duration of the interviewed beneficiaries has expired, it would be recommended that government should take training of the next set of beneficiaries seriously, most especially in the areas of rules and regulation governing the job and field practices. The state government should also retain the beneficiaries of N-Power Agro by giving them permanent appointments as this will add to the strength of the extension agents in the study area.

\section{References}

Abera, A. (2021). Determinants of participation in farmers training centre based extension training in Ethiopia. Journal of Agricultural Extension, 25(2), 86-95. https://dx.doi.org/10.4314/jae.v25i2.8. 
Creative Commons User License: CC BY-NC-ND

Abstracted by: EBSCOhost, Electronic Journals Service (EJS),

Google Scholar, Journal Seek, Scientific Commons,

Food and Agricultural Organization (FAO), CABI and Scopus
Journal of Agricultural Extension

Vol. 25 (4) October, 2021

ISSN(e): 24086851; ISSN(Print); 1119944X

http://journal.aesonnigeria.org

http://www.ajol.info/index.php/jae

Email: editorinchief@aesonnigeria.org

Adesina, T. K., \& Efuruoku, F. (2017). Determinants of participation in youth-in-agriculture programme in Ondo State, Nigeria. J. Agric. Ext. 21, 80-94.

Adeyanju, D. F. Mburu J., \& Mignouna, D. (2020). Impact of agricultural programs on youth engagement in agribusiness in Nigeria: A case study. Journal of Agricultural Science, $12(5), 145-154$.

Adeyanju, D. F., Mburu, J., \& Mignouna, D. (2021). Youth agricultural entrepreneurship: assessing the impact of agricultural training programmes on performance. Sustainability, 13, 1697. https://doi.org/10.3390/su13041697.

Akujuru, C. A., \& Enyioko, N. C. (2019). The impact of N-Power programmes on poverty alleviation in Nigeria: A study of Rivers State. Global Journal of Political Science and

Administration, 7(3), 29-50.

Bennel, P. (2017). Improving youth livelihoods in sub-Saharan Africa: A review of programmes with particular emphasis on the link between sexual behaviour and economic wellbeing. A report of the International Development Research Centre (IDRC) to the inter-poverty alleviation in Rivers State.

Bisong, D. B. (2019). Impact assessment of the N-power scheme: a study of southern senatorial district of Cross River State. Journal of Public Administration and Social Welfare Research, 4 (1), 31-38.

Latopa, A. A., \& AbdRashid, S. N. S. (2015). The impacts of integrated youth training farm as a capacity building center for youth agricultural empowerment in Kwara State, Nigeria. Mediterranean Journal of Social Sciences, 6 (5): 524-532.

N-Power Information Guide (2017). Federal Government of Nigeria national social investments programme. Retrieved 12 January, 2018 from www.npower.gov.ng/.

N-SIP. N-Power-N-SIP. (2019). Available online: https://n-sip.gov.ng/npower/ (accessed on 7 August 2021).

National Bureau of Statistic (2017). Annual Abstract of Statistics. Retrieved 12 January,

2018 from www.nigerianstat.gov.ng.

Odey, S. A. \& Sambe, N. (2019). Assessment of the contribution of N-Power Programme to youth empowerment in Cross River State, Nigeria. International Journal of Sociology and Anthropology Research, 5(4), 1-13.

Ogbette, A. S., Bernard-Oyoyo C. \& Okoh, J. O. (2019). All Progressives Congress (APC) $\mathrm{N}$-power programmes and unemployed Nigerians in Nigeria. Journal of Resources Development and Management, 54, 69-75.

Ogunmodede, A. M., Ogunsanwo, M. O. \& Manyong, V. (2020). Unlocking the potential of agribusiness in Africa through youth participation: An impact evaluation of N-power Agro Empowerment Program in Nigeria. Sustainability, 12, 5737. 
Creative Commons User License: CC BY-NC-ND

Abstracted by: EBSCOhost, Electronic Journals Service (EJS),

Google Scholar, Journal Seek, Scientific Commons,

Food and Agricultural Organization (FAO), CABI and Scopus

http://eoi.citefactor.org/10.11226/v25i4
Journal of Agricultural Extension

Vol. 25 (4) October, 2021

ISSN(e): 24086851; ISSN(Print); 1119944X

http://journal.aesonnigeria.org

http://www.ajol.info/index.php/jae

Email: editorinchief@aesonnigeria.org

Regasa, C., Ulimwenga J. \& Josee, R. (2016). Factors affecting performance of agricultural extension: evidence from democratic Republic of Congo. The Journal of Agricultural Education and Extension, 22(2), 113-143.

United States Agency for International Development [USAID] (2017). United States Agency for International Development. Briefing paper. Using information and communication technologies to enhance marketing for small agricultural producers. pp 1-5.

Yami, M., Feleke, S., Abdoulaye, T., Alene, A., Bamba, Z., \& Manyong, V. (2019). African rural youth engagement in agribusiness: achievements, limitations, and lessons. Sustainability, 11(1), 185. https://doi.org/10.3390/su11010185. 